\title{
Vitamin B6, B12, Asam Folat, Tekanan Darah dan Demensia pada Lanjut Usia
}

\section{Vitamin B6, B12, Folic Acid, Blood Pressure and Dementia in the Elderly}

\author{
Bekti Krisdyana $^{1 *}$, Diffah Hanim ${ }^{1}$, Sugiarto ${ }^{1,2}$
}

\section{ABSTRAK}

Latar Belakang: Demensia merupakan penyakit multifaktorial karena pengaruh genetik dan lingkungan. Minimnya asupan vitamin B6, B12, asam folat dan tekanan darah menjadi salah satu faktor lingkungan yang menyebabkan demensia.

Tujuan: Tujuan penelitian ini adalah menganalisis hubungan antara kecukupan vitamin B6, B12, asam folat dan tekanan darah dengan demensia pada lanjut usia

Metode: Penelitian ini berupa penelitian cross sectional, yang dilakukan di Kabupaten Tulungagung. Teknik sampling dengan cluster random sampling dan besar sampel 100 lansia dari 7 posyandu lansia di Kabupaten Tulungagung, dengan variabel bebas berupa kecukupan vitamin B6, B12, asam folat dan tekanan darah, sedangkan variabel terikatnya adalah demensia. Data dianalisis dengan uji chi square

Hasil: Responden penelitian ini umumnya berusia 60-74 tahun (70,0\%), wanita (48,0\%), berpendidikan terakhir SD/SMP $(60,0 \%)$ dan tidak bekerja $(69,0 \%)$. Kebanyakan responden memiliki kecukupan vitamin B6, B12 dan asam folat dalam kategori kurang, dengan persentase masing-masing 57,0 \%, $54 \%$ dan $64 \%$. Ditemukan hubungan antara kecukupan vitamin B6, B12 dan asam folat dengan demensia pada lanjut usia $(\mathrm{OR}=2,302 ; 95 \% \mathrm{Cl}=1,011-5,241 ; \mathrm{p}=0,045 ; \mathrm{OR}=2,397$; $95 \% \mathrm{Cl}=1,060-5,422 ; \mathrm{p}=0,034 ; \mathrm{OR}=2,516 ; 95 \% \mathrm{Cl}=1,015-6,238 ; \mathrm{p}=0,043)$. Tekanan darah berhubungan dengan demensia pada lanjut usia $(\mathrm{OR}=3,000 ; 95 \% \mathrm{Cl}=1,288-6,988 ; \mathrm{p}=0,010)$. Rata-rata konsumsi vitamin $\mathrm{B} 6, \mathrm{~B} 12$ dan asam folat kelompok normal lebih tinggi dibandingkan kelompok demensia, dengan selisih masing-masing sebesar 0,16 $\pm 0,04 \mathrm{mg}, 0,54 \pm 0,05 \mathrm{mcg}$ dan $65,89 \pm 4,95 \mathrm{mcg}$.

Kesimpulan: Terdapat hubungan antara kecukupan vitamin B6, B12, asam folat dan tekanan darah dengan demensia pada lanjut usia.

Kata Kunci: Vitamin B6, B12, Asam Folat, Tekanan Darah, Demensia, Lanjut Usia

\section{ABSTRACT}

Background: Dementia is a multifactorial disease due to genetic and environmental influences. Lack of intake of vitamins B6, B12, folic acid and blood pressure are one of the environmental factors that cause dementia.

Objective: To analyze the relationship between the adequacy of vitamins B6, B12, folic acid and blood pressure with dementia in the elderly

Method: This research was a cross sectional study, which was carried out in Tulungagung Regency. The sampling technique was cluster random sampling and a sample size of 100 elderly from 7 elderly Posyandu in Tulungagung Regency, with independent variables such as adequacy of vitamin B6, B12, folic acid and blood pressure, while the dependent variable was dementia. Data were analyzed with chi square test

Results: Respondents in this study were generally aged 60-74 years (70.0\%), women (48.0\%), were educated in elementary / junior high school (60.0\%) and did not work (69.0\%). Most respondents have insufficient vitamin B6, B12 and folic acid in the less category, with percentages of $57.0 \%, 54 \%$ and $64 \%$, respectively. There was an association between the adequacy of vitamins B6, B12 and folic acid with dementia in the elderly $(O R=2.302 ; 95 \% C l=1.011-5.241 ; p=0.045 ; O R=2.397 ; 95 \%$ $C l=1.060-5.422 ; p=0.034 ; O R=2.516 ; 95 \% C l=1.015-6.238 ; p=0.043)$. Blood pressure is associated with dementia in the elderly $(O R=3.000 ; 95 \% \mathrm{Cl}=1.288-6.988 ; p=0.010)$. The average consumption of vitamin $\mathrm{B} 6, \mathrm{B12}$ and folic acid in the normal group was higher than the dementia group, with a difference of $0.16 \pm 0.04 \mathrm{mg}, 0.54 \pm 0.05 \mathrm{mcg}$ and $65.89 \pm 4.95$ respectively mcg

Conclusion: There is a relationship between the adequacy of vitamins B6, B12, folic acid and blood pressure with dementia in the elderly.

Keywords: vitamin B6, B12, folic acid, blood pressure, dementia, eldelry. 


\author{
*Koresponden: \\ Bekti Krisdyana \\ bektikris85@gmail.com \\ ${ }^{1}$ Program Studi Ilmu Gizi, Pascasarjana Universitas Sebelas Maret Surakarta, Indonesia \\ ${ }^{2}$ Program Studi Ilmu Penyakit Dalam, Fakultas Kedokteran Universitas Sebelas Maret Surakarta, Indonesia
}

\section{PENDAHULUAN}

Usia 60 tahun ke atas menjadi batasan bagi seseorang untuk disebut sebagai lanjut usia (lansia) ${ }^{1}$. Jumlah lansia terus mengalami pertumbuhan seiring dengan terjadinya peningkatan usia harapan hidup. Indonesia memiliki jumlah lansia sebanyak 23,66 juta jiwa $(2017)^{2}$ dan jumlah ini diprediksi akan mengalami kenaikan lebih dari dua kali lipat pada tahun $2035^{3}$.

Usia lansia merupakan usia dimana banyak terjadi proses penuaan yang bersifat degeneratif yang memicu terjadinya penurunan berbagai fungsi tubuh ${ }^{4}$, yang salah satu akibatnya adalah terjadinya demensia ${ }^{5}$. Demensia ditandai oleh penurunan progresif fungsi kognitif yang mempengaruhi fungsi sosial dan kehidupan sehari-hari lansia ${ }^{6}$. Peningkatan populasi lansia di seluruh dunia mengakibatkan jumlah orang yang didiagnosa mengalami demensia semakin meningkat secara dramatis, terutama di negara-negara berpenghasilan rendah dan menengah ${ }^{6,7,8,9}$, jumlah kasus demensia diperkirakan akan berlipat ganda setiap 20 tahun ${ }^{7}$. Demensia adalah penyebab utama kecacatan, ketergantungan, dan penurunan kualitas hidup pada lansia dan menimbulkan banyak tantangan sosial, ekonomi, dan perawatan kesehatan yang akan terus meningkat seiring dengan peningkatan populasi lansia ${ }^{9}$. Dilaporkan bahwa dampak ekonomi akibat demensia melebihi jumlah biaya yang dibutuhkan untuk penanganan penyakit kanker dan kardiovaskuler ${ }^{10}$.

Demensia merupakan penyakit multifaktorial yang disebabkan oleh faktor genetik dan lingkungan ${ }^{11}$. Minimnya asupan vitamin B6, B12, asam folat dan tekanan darah menjadi salah satu faktor lingkungan yang menyebabkan demensia ${ }^{12,13,14}$. Vitamin B6, B12 dan asam folat merupakan nutrisi yang dibutuhkan untuk mempertahankan kadar homeosistein dalam kondisi normal. Peningkatan kadar homosistein akan mengganggu fungsi vaskuler dan menyebabkan toksik pada neuron sehingga meningkatkan resiko terjadinya demensia ${ }^{15}$. Pemberian suplemen vitamin B6, B12 dan asam folat memberikan efek yang menguntungkan terhadap fungsi kognitif global dan memori ${ }^{16}$. Semakin meningkat kadar folat di dalam tubuh, maka fungsi kognitif juga akan semakin baik (untuk tes kecekatan psikomotorik), mekanisme vaskuler berkaitan dengan proses ini ${ }^{17}$.

Penyebab demensia yang lainya adalah adanya gangguan pada otak akibat tekanan darah tinggi ${ }^{18}$. Tekanan darah tinggi adalah kondisi yang sangat umum, terjadi pada sepertiga dari orang dewasa dunia dan pada dua pertiga orang dewasa di atas usia 65 tahun ${ }^{19}$. Penduduk usia di atas 18 tahun yang mengalami tekanan darah tinggi di Indonesia, naik sebesar 8,3 \% (25,8 \% pada tahun 2013 dan $34,1 \%$ pada tahun 2018) $)^{20}$. Tekanan darah tinggi dan demensia merupakan permasalahan kesehatan terkait faktor usia yang dapat menyebabkan kecacatan ${ }^{21}$.
Terdapat hubungan positif antara tekanan darah di usia paruh baya dengan resiko kerusakan kognitif atau demensia yang lebih tinggi pada usia lanjut, sehingga tekanan darah tinggi menjadi faktor risiko penting terjadinya demensia 22.23 . Efek tekanan darah ini terjadi melalui berbagai mekanisme yang berdampak pada penurunan fungsi kognitif dan demensia ${ }^{24}$, diantaranya melalui perubahan fungsi vaskuler akibat penurunan aliran darah otak, sehingga mengganggu fungsi memori dan fungsi kognisi lainnya ${ }^{25}$.

Lokasi penelitian ini adalah di posyandu lansia wilayah Kabupaten Tulungagung. Kabupaten Tulungagung memiliki prevalensi lansia sebesar 15,25\%, prevalensi ini berada di atas prevalensi Provinsi Jawa Timur dan Indonesia ${ }^{26}$. Penelitian ini perlu dilakukan karena penelitian mengenai hubungan antara kecukupan vitamin B6, B12, asam folat dan tekanan darah dengan demensi pada lanjut usia masih terbatas dan menghasilkan kesimpulan yang bervariasi. Maksud dari penelitian ini adalah untuk menganalisis hubungan antara kecukupan vitamin B6, B12, asam folat dan tekanan darah dengan demensia pada lanjut usia di Kabupaten Tulungagung.

\section{METODE}

Penelitian ini dirancang sebagai penelitian cross sectional, yang dilakukan di 7 posyandu wilayah Kabupaten Tulungagung selama bulan Desember 2019 sampai dengan Januari 2020.

Data diambil pada lansia dengan umur $\geq 60$ tahun di wilayah Kabupaten Tulungagung, dengan total responden sebanyak 100 orang. Teknik sampling dilakukan dengan cluster random sampling. Syarat responden yang menjadi sampel adalah memenuhi kriteria yang telah ditetapkan. Lansia yang berusia $\geq 60$ tahun, bersedia menjadi responden, dapat beraktivitas sehari-hari secara mandiri, dapat berkomunikasi dengan baik, dapat membaca, menulis dan mendengar dengan baik, tinggal bersama keluarga dan rutin mengikuti posyandu lansia dan senam lansia, digunakan sebagai sampel. Sementara itu, lansia yang tinggal di panti, lansia yang minum obat hipertensi dalam 1 bulan terakhir, lansia yang memiliki gangguan kesehatan seperti diabetes mellitus, kelainan jantung, stroke, trauma kepala dan lansia yang minum suplemen/multivitamin, dikeluarkan dari sampel penelitian. Lansia yang bersedia menjadi responden, diminta menandatangani form persetujuan.

Usia, gender, pendidikan, pekerjaan, asupan vitamin B6, B12, asam folat dan tekanan darah menjadi variabel bebas, sedangkan variabel terikatnya adalah demensia. Pengumpulan data dilakukan di posyandu lansia dengan wawancara menggunakan kuesioner dan pengukuran tekanan darah. Data usia, gender, pendidikan dan pekerjaan diperoleh melalui wawancara lansung kepada responden menggunakan kuesioner. 
Data usia, dikelompokkan menjadi lanjut usia, jika usia antara 60-74 tahun dan lanjut usia tua, jika usia $\geq 75$ tahun. Data gender dikategorikan menjali pria dan wanita. Data pendidikan dikelompokkan menjadi dasar, jika tamat SD dan SMP, menengah, jika tamat sekolah menengah atas dan tinggi, jika tamat perguruan tinggi. Data pekerjaan dikelompokkan menjadi bekerja, jika responden masih bekerja dan tidak bekerja, jika responden tidak bekerja.

Data kecukupan vitamin B6, B12, asam folat dikumpulkan menggunakan semi kuantitatif food frequency quessionnaire, yaitu dengan menggali informasi tentang bahan makanan yang dikonsumsi selama 1 bulan. Data kecukupan ini selanjutnya diolah menjadi asupan rata-rata harian dan dimasukkan ke dalam program nutrisurvey 2007 untuk diketahui asupan vitamin B6, B12 dan asam folat responden. Data kecukupan ini diambil oleh peneliti dan enumerator sebanyak satu kali. Kecukupan vitamin B6, B12 dan asam folat dikategorikan menjadi cukup, jika asupan $\geq 77 \%$ AKG dan kurang, jika asupan $<77 \%{ }^{27}$. Responden diukur tekanan darah menggunakan sphygnomanometer yang dilakukan oleh petugas kesehatan pada masing-masing posyandu lansia. Tekanan darah dikategorikan menjadi normal, jika $<140 / 90 \mathrm{mmHg}$ dan tekanan darah tinggi, jika $\geq 140 / 90 \mathrm{mmHg}^{28}$. Data demensia diperoleh dengan wawancara menggunakan kuesioner Mini Mental Status Exam/MMSE. Menurut Kaplan (2010) ada beberapa tes yang dapat membantu diagnosa demensia di masyarakat, salah satunya adalah kuesioner Mini Mental
Status Exam $(\mathrm{MMSE})^{29}$. MMSE berfungsi dalam melakukan penilaian terhadap fungsi kognitif secara umum sebagai alat penapis demensia ${ }^{30}$. Kuesioner MMSE dilakukan oleh perawat jiwa, hasilnya dikategorikan menjadi normal, jika nilai kognitif 24-30 dan demensia, jika nilai kognitif $<24^{31}$. Analisis data dilakukan menggunakan uji chi square

Penelitian ini memperoleh status layak etik dari Komisi Etik Penelitian Kesehatan Universitas Sebelas Maret (No. 364/UN27.06/KEPK/EC/2019), perijinan dari Badan Kesatuan Bangsa, Politik dan Perlindungan Masyarakat Provinsi Jawa Timur (No. 070/12482/209.4/2019), Badan Kesatuan Bangsa, Politik dan Perlindungan Masyarakat Kabupaten Tulungagung (No. 072/312/601/2019) dan Dinas Kesehatan Kabupaten Tulungagung (No. 072/4735/103/2019).

\section{HASIL DAN PEMBAHASAN}

Penelitian ini dilakukan pada 100 subjek lansia dengan rentang usia 60 sampai 83 tahun. Tabel 1 menunjukkan bahwa responden yang tidak mengalami demensia maupun yang mengalami demensia sebagian besar dalam kelompok lanjut usia (60-74 tahun), masingmasing $80,4 \%$ dan $56,8 \%$. Sebagian besar responden dengan demensia, berjenis kelamin perempuan $(54,5$ $\%)$, berpendidikan dasar $(63,6 \%)$ dan tidak bekerja $(68,2$ $\%)$. Keadaan ini sama dengan responden yang berada dalam kelompok normal atau tidak mengalami demensia.

Tabel 1. Tabulasi Silang

\begin{tabular}{|c|c|c|c|c|c|}
\hline \multirow{2}{*}{ Variabel } & \multicolumn{2}{|c|}{ Normal } & \multicolumn{2}{|c|}{ Demensia } & \multirow{2}{*}{$p$-value } \\
\hline & $\mathrm{n}$ & $\%$ & $\mathrm{n}$ & $\%$ & \\
\hline \multicolumn{6}{|l|}{ Usia } \\
\hline Lanjut usia & 45 & 80,4 & 25 & 56,8 & $0,011^{*}$ \\
\hline Lanjut usia tua & 11 & 19,6 & 19 & 43,2 & \\
\hline \multicolumn{6}{|l|}{ Gender } \\
\hline Pria & 22 & 39,3 & 20 & 45,5 & 0,535 \\
\hline Wanita & 24 & 60,7 & 24 & 54,5 & \\
\hline \multicolumn{6}{|l|}{ Pendidikan } \\
\hline Dasar & 32 & 57,1 & 28 & 63,6 & 0,511 \\
\hline Menengah & 24 & 42,9 & 16 & 36,4 & \\
\hline \multicolumn{6}{|l|}{ Pekerjaan } \\
\hline Bekerja & 17 & 30,4 & 14 & 31,8 & 0,875 \\
\hline Tidak Bekerja & 39 & 69,6 & 30 & 68,2 & \\
\hline \multicolumn{6}{|l|}{ Vitamin B6 } \\
\hline Cukup & 29 & 51,8 & 14 & 31,8 & $0,045^{*}$ \\
\hline Kurang & 27 & 48,2 & 30 & 68,2 & \\
\hline \multicolumn{6}{|l|}{ Vitamin B12 } \\
\hline Cukup & 31 & 55,4 & 16 & 34,1 & $0,034^{*}$ \\
\hline Kurang & 25 & 44,6 & 29 & 65,9 & \\
\hline \multicolumn{6}{|l|}{ Asam Folat } \\
\hline Cukup & 22 & 39,3 & 9 & 20,5 & $0,043 *$ \\
\hline Kurang & 34 & 60,7 & 35 & 79,5 & \\
\hline \multicolumn{6}{|l|}{ Tekanan Darah } \\
\hline Normal & 42 & 75,0 & 22 & 50,0 & $0,010^{*}$ \\
\hline Tekanan darah tinggi & 14 & 25,0 & 22 & 50,0 & \\
\hline
\end{tabular}

*hubungan yang signifikan, yaitu $p<\alpha, \alpha=0,05$

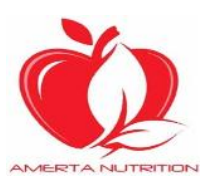


Responden dengan demensia, 68,2 \% memiliki tingkat kecukupan vitamin B6 dalam kategori kurang, sedangkan pada responden normal tergolong cukup sebesar 51,8 \% (Tabel 1). Angka Kecukupan Gizi (AKG) vitamin B6 untuk usia di atas 60 tahun sebesar 1,7 mg bagi laki-laki dan $1,5 \mathrm{mg}$ bagi perempuan ${ }^{32}$. Kecukupan vitamin B12 responden dengan status demensia normal, sebagian besar tergolong cukup (55,4\%). Sementara itu, untuk responden yang mengalami demensia tergolong kurang sebanyak $65,9 \%$. AKG untuk vitamin B12 pada lansia sebesar $4 \mu \mathrm{g}$ baik untuk laki-laki maupun perempuan $^{32}$. Responden yang tidak mengalami demensia, sebagian besar memiliki asupan asam folat dalam kategori kurang sebanyak 34 responden $(60,7 \%)$, sedangkan untuk responden demensia sebanyak 35 responden (79,5\%). Nilai AKG untuk asam folat bagi lansia sebesar $400 \mu \mathrm{g}^{32}$. Tekanan darah pada responden yang tidak mengalami demensia dalam kategori normal sebanyak $75 \%$ dan untuk responden dengan demensia hanya $50 \%$ memiliki tekanan darah tinggi. Usia $\geq 75$ tahun, asupan vitamin B6 kurang, asupan vitamin B12 kurang, asupan asam folat kurang dan tekanan darah tinggi menjadi faktor resiko terjadinya demensia pada lanjut usia (tabel 2) dengan nilai prevalens rasio (PR) masing-masing sebesar $1,77(95 \% \mathrm{Cl} 1,28-7,56), 1,62$ (95\% Cl 1,01-5,24), 1,58 (95\% Cl 1,06-5,42), 1,75 (95\% Cl $1,01-6,24)$ dan 1,78 (95\% Cl 1,29-6,99)

Dari penelitian ini, diperoleh informasi bahwa terdapat hubungan antara usia dengan demensia pada lanjut usia $(p=0,011)$, dimana orang yang berusia $\geq 75$ tahun lebih banyak memiliki risiko mengalami demensia sebesar 1,77 kali dibandingkan lansia usia $<75$ tahun. Penelitian Baroni dkk (2019) juga menemukan bahwa terdapat korelasi antara faktor umur dengan gangguan fungsi kognitif, dimana penurunan fungsi kognitif sejalan dengan pertambahan usia ${ }^{33}$. Dari segi gender, ditemukan bahwa tidak terdapat hubungan antara gender (laki-laki dan perempuan) dengan demensia. Hasil ini sesuai dengan penelitian Ruteinberg dkk (2011) menyatakan bahwa peluang kejadian demensia pada lansia usia 60-89 tahun adalah sama pada laki-laki dan perempuan. Peranan gender baru terlihat setelah usia 90 tahun dimana lansia perempuan memiliki risiko (OR) 2,61 kali lebih besar untuk mengalami demensia dibandingkan lansia laki-laki. Derajat keparahan demensia pada lansia perempuan juga 5,79 kali lebih tinggi dibandingkan lansia laki-laki ${ }^{34}$. Selanjutnya, pendidikan tidak berhubungan dengan kejadian demensia $(p=0,511)$ dan tidak sesuai dengan penelitian Maryam dkk (2015) yang menemukan bahwa antara tingkat pendidikan dengan demensia pada lanjut usia memiliki hubungan yang bermakna, semakin rendah tingkat pendidikan maka peluang untuk mengalami demensia lebih besar $(O R=10,831,95 \% \mathrm{Cl} 1,397-$ $83,983)^{35}$. Perbedaan hasil penelitian ini dengan Maryam adalah karena terdapat perbedaan sasaran dan lokasi penelitian, dimana penelitian Maryam dilakukan pada sampel lanjut usia yang tinggal di panti sosial dan data diambil di panti tempat lansia tinggal ${ }^{35}$. Penelitian di Jepang menemukan bahwa faktor sosial ekonomi yang paling berpengaruh terhadap terjadinya demensia pada usia di atas 65 tahun adalah tingkat pendidikan. Riwayat pendidikan lebih dari 13 tahun menurunkan resiko terjadinya demensia pada lansia ${ }^{36}$. Sebagian besar responden dari penelitian ini berpendidikan tamat SD dan SMP, bahkan tidak ada yang berpendidikan tamat perguruan tinggi, padahal seseorang yang memiliki pendidikan yang semakin baik, akan lebih mampu pula dalam beradaptasi dengan perubahan kognitif dan neurogenertif, sehingga resiko kejadian demensia pada lanjut usia dapat ditekan ${ }^{37}$.

Tabel 2. Prevalent Ratio (PR) Usia, Asupan Vitamin B6, B12, Asam Folat dan Tekanan Darah terhadap Demensia pada Responden

\begin{tabular}{lcc}
\hline \multicolumn{1}{c}{ Variabel } & PR & $95 \% \mathrm{Cl}$ \\
\hline Usia (Lanjut usia tua) & 1,77 & $1,28-7,56$ \\
Asupan Vitamin B6 (Kurang) & 1,62 & $1,01-5,24$ \\
Asupan Vitamin B12 (Kurang) & 1,58 & $1,06-5,42$ \\
Asupan Asam Folat (Kurang) & 1,75 & $1,01-6,24$ \\
Tekanan Darah (Tekanan darah tinggi) & 1,78 & $1,29-6,99$ \\
\hline
\end{tabular}

Pekerjaan responden juga tidak berhubungan dengan demensia pada lanjut usia $(p=0,875)$. Meskipun pekerjaan tidak berhubungan dengan demensia, tetapi responden yang mengalami demensia cenderung tidak bekerja. Pekerjaan menjadi salah satu faktor resiko munculnya demensia. Resiko demensia dapat diturunkan jika kemampuan kognitif pada lansia terus diasah, diantaranya melalui kegiatan bekerja. Kombinasi penggunaan tenaga dan fikiran selama bekerja memiliki resiko lebih kecil mengalami demensia dibandingkan dengan yang hanya mengandalkan tenaga atau fikiran saja. Pekerjaan yang cenderung mengandalkan tenaga, berkaitan dengan peningkatan resiko kematian demensia $^{38}$. Sementara itu Takasugi dkk (2019) menemukan bahwa pria yang bekerja sebagai tenaga terampil memiliki insiden demensia yang lebih rendah dibandingkan dengan tenaga teknis dan tidak terdapat hubungan yang signifikan antara pekerjaan dengan kejadian demensia pada wanita ${ }^{36}$.

Penelitian ini menunjukkan bahwa asupan vitamin B6 berhubungan dengan demensia pada lajut usia $(p=0,045)$. Lanjut usia dengan asupan vitamin B6 yang kurang berisiko mengalami demensia sebesar 1,62 kali dibandingkan dengan yang memiliki asupan cukup. Hasil ini sesuai dengan penelitian Pratiwi dkk (2013) yang melaporkan bahwa kejadian demensia pada lanjut usia berhubungan secara negatif dengan konsumsi vitamin B6, artinya asupan vitamn B6 yang semakin rendah, maka status demensianya akan semakin parah ${ }^{14}$. Kim dkk (2014), juga menemukan bahwa rendahnya asupan vitamin $\mathrm{B} 6$ yang bersumber dari makanan, berhubungan dengan penurunan fungsi kognitif ${ }^{39}$. Vitamin B6 memiliki 
peran dan fungsi yang penting dalam kesehatan otak dan sistem saraf ${ }^{40,41}$, salah satunya adalah dalam sintesis berbagai neurotransmiter termasuk dopamin dan serotonin $^{42}$. Selain itu, asupan vitamin B6 yang lebih tinggi dikaitkan dengan volume gray matter yang lebih besar $^{43}$ dan pemberian suplemen vitamin B6 telah terbukti memperlambat atrofi otak, sehingga menghambat penurunan fungsi kognitif yang dapat menyebabkan demensia ${ }^{44}$. Makanan sumber vitamin B6 yang paling sering dikonsumsi oleh lansia adalah pisang dengan frekuensi konsumsi 4-5 kali per minggu.

Kecukupan vitamin B12 berhubungan dengan demensia pada responden penelitian ini $(p=0,034)$. Resiko kejadian kejadian demensia pada lansia dengan asupan vitamin B12 yang kurang sebesar 1,58 kali dibandingkan dengan yang memiliki asupan cukup. Moore dkk (2012) memperoleh hasil bahwa level serum vitamn B12 yang rendah berkaitan dengan penyakit neurodegeneratif dan kemunduran kognitif ${ }^{45}$. Vitamin B12 terlibat dalam menjaga fungsi sistem saraf normal karena perannya dalam konversi homosistein menjadi metionin. Asupan makanan yang kurang optimal ditambah dengan faktor usia, dapat mengganggu penyerapan dan metabolisme vitamin B12 sehingga menyebabkan disregulasi siklus homosistein dan peningkatan kadar homosistein darah yang mengakibatkan terjadinya neurotoksik yang memicu demensia $^{46}$. Feldman dkk (2008) menemukan bahwa kekurangan vitamin B12 dapat menyebabkan defisit neurologis. Kejadian demensia yang disebabkan oleh kekurangan B12 bersifat reversibel ${ }^{47}$.

Tingkat vitamin B12 pada manusia tergantung pada asupan dan penyerapan protein yang berasal dari hewan. Sumber viramin B12 yang paling sering dikonsumsi lansia dalam penelitian ini adalah ikan pindang (4-6 kali per minggu) dan ikan bandeng (3-4 kali per minggu). Defisiensi vitamin B12 berhubungan dengan faktor usia. Rendahnya vitamin B12, yang biasa terjadi sebagai akibat penurunan metabolisme pada lanjut usia, telah dianggap sebagai penyebab demensia yang reversibel. Beberapa penelitian menunjukkan bahwa hubungan antara vitamin B12 dan fungsi kognitif dianalisis berdasarkan studi yang melibatkan homosistein. Homosistein merupakan salah satu jenis amino acid yang memiliki kandungan sulfur dan juga merupakan asam amino yang sebagian besar berasal jalur metionin, di mana defisit vitamin B12 atau asam folat akan mengakibatkan peningkatan kadar homosistein. Total level homosistein juga meningkat dengan bertambahnya usia. Kadar vitamin B12, asam folat dan fungsi ginjal menjadi faktor terpenting dalam menentukan konsentrasi homosistein ${ }^{48}$. Peningkatan homosistein menjadi faktor risiko pengembangan penyakit serebrovaskular, demensia Tipe Alzheimer (AD), dan demensia vaskular ${ }^{49}$.

Berdasarkan tabel 1, dapat diketahui bahwa asupan asam folat berhubungan secara signifikan dengan kejadian demensia $(p=0,043)$ dan lansia dengan asupan asam folat yang kurang mempunyai resiko 1,75 kali lebih besar dibandingkan dengan asupan yang cukup. Jeruk (5-6 kali per minggu) merupakan bahan makanan sumber asam folat yang paling sering dikonsumsi responden. Folat bersama dengan vitamin B12, berperan dalam membantu perubahan homosistein menjadi metionin ${ }^{50}$. Rendahnya asupan folat dan vitamin B12 mengakibatkan rendahnya konsentrasi folat dan vitamin B12 dan hal ini menjadi faktor penyebab utama peningkatan kadar homosistein (hiperhomosisteinemia) $^{33}$.

Hiperhomosisteinemia telah lama dicurigai sebagai faktor risiko penyakit pembuluh darah ${ }^{50}$ dan berhubungan dengan penyakit kardiovaskuler ${ }^{51}$ serta menjadi faktor resiko independen terjadinya demensia $^{52}$. Hal serupa ditemukan oleh Morris and Jacques (2010) yang menyatakan bahwa kadar asam folat yang rendah dan tingginya kadar homosistein merupakan faktor risiko untuk depresi dan terutama demensia, termasuk penyakit Alzheimer dan demensia vaskular $^{49}$. Kadar homosistein yang tinggi dapat memengaruhi kognisi melalui mekanisme multipel diantaranya stres oksidatif, apoptosis, dan plak pikun $^{53,54}$. Kenaikan plasma homosistein menyebabkan atropi pada lobus temporal medial yang lebih cepat yang menyebabkan gangguan fungsi kognitif dan demensia ${ }^{49}$. Pemberian suplemen vitamin B6, B12 dan asam folat selama 2 tahun, terbukti dapat memperlambat laju penurunan kognitif dan atropi otak pada lanjut usia dengan gangguan kognitif ringan ${ }^{16}$.

Tekanan darah memiliki hubungan dengan kejadian demensia $(p=0,010)$ dan lansia yang mengalami tekanan darah tinggi beresiko 1,78 kali mengalami demensia dibandingkan dengan yang memiliki tekanan darah normal. Tekanan darah tinggi sering terjadi pada lanjut usia, lebih dari $70 \%$ terjadi individu berusia 70 $79^{19}$. Peningkatan tekanan darah pada lanjut usia secara signifikan terkait dengan kenaikan risiko gangguan kognitif $^{55,56,57}$ dan demensia ${ }^{22}$. Mekanisme yang menjelaskan hubungan antara tekanan darah dan gangguang fungsi kognitif, sebagai tanda awal terjadinya demensia, sangat kompleks ${ }^{58}$. Tekanan darah tinggi mengubah struktur dan fungsi serebrovaskular, yang menyebabkan lesi otak seperti cerebral atrophy, stroke, infark lacunar, kerusakan white matter, perdarahan pembuluh darah dan pada akhirnya mengakibatkan gangguan kognitif ${ }^{59}$.

Tekanan darah tinggi juga mengganggu metabolisme dan transfer protein amiloid- $\beta$ (AB), sehingga mempercepat penurunan kognitif, yang merupakan jalur terjadinya demensia. Tekanan darah tinggi menginduksi demensia dengan mengaktifkan Reseptor Advanced Glycation Endproducts (RAGE) melalui stres oksidatif dan pembentukan produk glikasi. RAGE diaktifkan oleh tekanan darah tinggi yang terjadi di otak. Pembuluh darah serebral merupakan pertahanan pertama bagi otak dari perubahan hemodinamik pada perifer, termasuk tekanan darah tinggi. Reseptor RAGE diekspresikan pada sel endotel dan ekspresinya dimodulasi oleh beberapa faktor humoral dan peningkatan sirkulasi darah. Hipertensi berpengaruh terhadap regulasi RAGE di korteks dan hippocampus, yang ditunjukkan oleh adanya akumulasi RAGE pada pembuluh darah otak. Kondisi ini menghambat masuknya protein amiloid- $\beta$ (A $\beta)$ ke dalam otak, 
sehingga menyebabkan kerusakan otak dan penurunan fungsi kognitif (demensia) ${ }^{60}$.

Beberapa studi menunjukkan bahwa kejadian demensia meningkat dan berkaitan dengan adanya gangguan serebrovaskuler, yang sangat erat kaitannya dengan hipertensi. Penelitian pada hewan, menemukan bahwa kejadian demensia terkait dengan iskemia pada serebral yang menginisiasi demensia melalui peningkatan ekspresi gen protein prekusor amiloid ${ }^{60}$. Mekanisme demensia yang disebabkan oleh hipertensi, melibatkan beta amiloid peptida yang berkumpul membentuk plak neuritik yang menyebabkan kerusakan neuron dan mengganggu fungsi kogntif, sehingga mengakibatkan munculnya demensia ${ }^{61}$.

Berdasarkan tabel 3, dapat diketahui bahwa ratarata asupan vitamin B6 pada kelompok normal sebesar
1,17 $\pm 0,47 \mathrm{mg}$ dan pada kelompok demensia sebesar $1,01 \pm 0,43 \mathrm{mg}$. Asupan vitamin B6 pada kelompok tidak demensia lebih tinggi dibandingkan kelompok yang mengalami demensia. Proses metabolisme homosistein dikatalis oleh vitamin B6. Jalur transulfurasi mengubah homosistein menjadi sistationin dengan cara menyatukan homosistein dengan serin melalui suatu reaksi yang dikatalisa oleh vitamin B6. Sistationin yang terbentuk, akan terhidrolisa menjadi sistein atau glutation yang akan dimetabolisme menghasilkan sulfat dan dikeluarkan melalui urin sehingga kadar homosistein dalam tubuh dapat dikendalikan ${ }^{62}$. Demensia juga berhubungan dengan beberapa faktor yang tidak diteliti pada penelitian ini seperti riwayat demensia keluarga ${ }^{63}$, merokok ${ }^{64}$, aktivitas fisik $^{65}$ dan tingkat stres ${ }^{66}$.

Tabel 3. Rata-rata Asupan Vitamin B6, B12 dan Asam Folat pada Responden

\begin{tabular}{lcc}
\hline \multicolumn{1}{c}{ Variabel } & Normal & Demensia \\
\hline Vitamin B6 & $1,17 \pm 0,47 \mathrm{mg}$ & $1,01 \pm 0,43 \mathrm{mg}$ \\
\hline Vitamin B12 & $2,62 \pm 1,51 \mathrm{mcg}$ & $2,08 \pm 1,46 \mathrm{mcg}$ \\
\hline Asam Folat & $246,18 \pm 119,41 \mathrm{mcg}$ & $180,29 \pm 114,46 \mathrm{mcg}$ \\
\hline
\end{tabular}

Rata-rata asupan vitamin B12 pada kelompok yang normal sebesar 2,62 $\pm 1,51 \mathrm{mcg}$, sedangkan pada kelopok demensia sebesar 2,08 $\pm 1,46 \mathrm{mcg}$. Kelompok yang mengalami demensia memiliki asupan vitamin B12 yang lebih rendah dibandingkan kelompok normal. Demikian juga untuk rata-rata asupan asam folat, dimana pada kelompok normal, memiliki rata-rata asupan yang lebih baik dibandingkan pada kelompok demensia, masing-masing sebesar 246,18 $\pm 119,41 \mathrm{mcg}$ dan 180,29 $\pm 114,46 \mathrm{mcg}$. Vitamin B12 mempunyai peran yang penting dalam fungsi neuron secara normal. Vitamin B12 dan asam folat secara bersama-sama membantu perubahan homosistein menjadi metionin ${ }^{45}$. Kadar homosistein yang tinggi dapat menyebabkan gangguan fungsi kognitif melalui perubahan vaskuler dan toksik pada neuron secara langsung ${ }^{46}$. Vitamin B6, B12 dan asam folat secara metabolik saling terkait dalam metabolisme satu karbon, sehingga ketiga jenis vitamin ini berhubungan terbalik dengan kadar homosistein. Dalam metabolisme satu karbon, homosistein merupakan produk sampingan dari metabolisme metionin, yang terbentuk dari donor metil SAM (S-adenosy/methionine) selama metilasi biomolekul dan hidrolisis (SAH) S-adenosylhomocysteine menjadi homosistein. Homosistein yang terbentuk akan mengalami remetilasi menjadi metionin oleh methylenetetrahydrofolate. Di dalam siklus satu karbon, penurunan homosistein oleh vitamin B (B6, B12 dan asam folat) secara metabolik saling terkait ${ }^{67}$.

Keterbatasan penelitian ini antara lain terdapat beberapa faktor yang berkaitan dengan kejadian demensia pada lansia yang tidak diteliti, diantaranya riwayat demensia keluarga, riwayat penyakit, aktivitas fisik dan tingkat stress.

\section{KESIMPULAN}

Berdasarkan hasil penelitian ini, dapat disimpulkan bahwa terdapat hubungan antara kecukupan vitamin B6, B12, asam folat dan tekanan darah dengan demensia pada lanjut usia. Rata-rata asupan vitamin B6, B12 dan asam folat lebih baik pada kelompok yang normal (tidak mengalami demensia). Hasil penelitian ini menunjukkan bahwa usia, asupan vitamin B6, B12, asam folat dan tekanan darah tinggi dapat menjadi faktor risiko terjadinya demensia. Sosialisasi dan edukasi tentang asupan zat gizi, khususnya vitamin B6, B12 dan asam folat perlu dilakukan kepada lansia dan masyarakat agar kejadian demensia dapat diminimalisir. Manajemen tekanan darah pada lansia yang dilakukan di posyandu ataupun di puskesmas penting dilakukan untuk menjaga vitalitas kognitif.

\section{ACKNOWLEDGEMENT}

Peneliti mengucapkan terima kasih kepada semua pihak yang membantu proses penelitian ini. Ucapan terima kasih juga peneliti sampaikan kepada Badan Kesatuan Bangsa, Politik dan Perlindungan Masyarakat Provinsi Jawa Timur dan Kabupaten Tulungagung, Dinas Kesehatan Kabupaten Tulungagung dan seluruh puskesmas yang berpartisipasi dalam penelitian ini.

\section{REFERENSI}

1. Biro Hukum \& Humas BPKP. Peraturan Pemerintah Republik Indonesia Nomor 43 Tahun 2004. in Peraturan Pemerintah Republik Indonesia Nomor 43 Tahun 2004 (2004). doi:10.1055/s-2007-1025018.

2. Badan Pusat Statistik. Profil Penduduk Indonesia Hasil SUPAS 2015. Badan Pusat Statistik (2015).

3. Badan Pusat Statistik Indonesia. Indonesia Population Projection 2010-2035. Badan Pusat Statistik Indonesia (2013). doi:2101018.

4. Fatmah. Gizi Usia Lanjut. Jakarta: Penerbit Erlangga (2010).

5. Wysocki, M. et al. Hypertension is associated with cognitive decline in elderly people at high risk for dementia. Am. J. Geriatr. Psychiatry 20, 
179-187 (2012).

6. Prince, M. et al. The Global Impact of Dementia - An analysis of prevalence, incidence, cost and trends. Alzheimer's Dis. Int. 84, (2015).

7. Prince, M. et al. The global prevalence of dementia: A systematic review and metaanalysis. Alzheimer's Dement. 9, 63-75 (2013).

8. Rocca, W. A. et al. Trends in the incidence and prevalence of Alzheimer's disease, dementia, and cognitive impairment in the United States. Alzheimer's Dement. 7, 80-93 (2011).

9. Larson, E. B. \& Langa, K. M. The rising tide of dementia worldwide. Lancet 372, 464 (2008).

10. Alzheimer's Disease International (ADI). World Alzheimer Report 2010: The Global Economic Impact of Dementia. Alzheimer's Dis. Int. (ADI) 1-52 (2010) doi:10.1111/j.09637214.2004.00293.x.

11. Migliore, L. \& Coppedè, F. Genetics, environmental factors and the emerging role of epigenetics in neurodegenerative diseases. Mutat. Res. - Fundam. Mol. Mech. Mutagen. 667, 82-97 (2009).

12. Osimani, A., Berger, A., Friedman, J., Porat-Katz, B. S. \& Abarbanel, J. M. Neuropsychology of vitamin B12 deficiency in elderly dementia patients and control subjects. J. Geriatr. Psychiatry Neurol. 18, 33-38 (2005).

13. Blasko, I. et al. Conversion from mild cognitive impairment to dementia: Influence of folic acid and vitamin b12 use in the vita cohort. J. Nutr. Heal. Aging 16, 687-694 (2012).

14. Pratiwi, C. U., Marliyati, S. A. \& Latifah, M. Pola Konsumsi Pangan, Aktivitas Fisik, Riwayat Penyakit, Riwayat Demensia Keluarga dan Kejadian Demensia pada Lansia di Panti Werdha Tresna Bogor. J. Gizi dan Pangan 8, 129 (2014).

15. Aisen, P. S. et al. High-dose B vitamin supplementation and cognitive decline in Alzheimer disease: A randomized controlled trial. JAMA - J. Am. Med. Assoc. 300, 1774-1783 (2008).

16. De Jager, C. A., Oulhaj, A., Jacoby, R., Refsum, H. \& Smith, A. D. Cognitive and clinical outcomes of homocysteine-lowering B-vitamin treatment in mild cognitive impairment: $A$ randomized controlled trial. Int. J. Geriatr. Psychiatry 27, 592-600 (2012).

17. De Lau, L. M. L., Refsum, H., Smith, A. D., Johnston, C. \& Breteler, M. M. B. Plasma folate concentration and cognitive performance: Rotterdam Scan Study. Am. J. Clin. Nutr. 86, 728-734 (2007).

18. Zhao, Y., Wu, G., Shi, H., Xia, Z. \& Sun, T. Relationship between cognitive impairment and apparent diffusion coefficient values from magnetic resonance-diffusion weighted imaging in elderly hypertensive patients. Clin. Interv. Aging 9, 1223-1231 (2014).

19. Mills, K. T. et al. Global Disparities of Hypertension Prevalence and Control: A
Systematic Analysis of Population-Based Studies From 90 Countries. Circulation 134, 441-450 (2016).

20. Kemenkes RI. Laporan Nasional RISKEDAS 2018. Badan Penelitian dan Pengembangan Kesehatan Riset (2019).

21. Duron, E. \& Hanon, O. Vascular risk factors, cognitve decline, and dementia. Vasc. Health Risk Manag. 4, 363-381 (2008).

22. Alpérovitch, A. et al. Blood pressure variability and risk of dementia in an elderly cohort, the Three-City Study. Alzheimer's Dement. 10, S330-S337 (2014).

23. Liang, X. et al. Hypertension and high blood pressure are associated with dementia among Chinese dwelling elderly: The Shanghai aging study. Front. Neurol. 9, (2018).

24. Thorvaldsson, V. et al. Nonlinear blood pressure effects on cognition in old age: Separating between-person and within-person associations. Psychol. Aging 27, 375-383 (2012).

25. Igase, M., Kohara, K. \& Miki, T. The association between hypertension and dementia in the elderly. Int. J. Hypertens. 1-6 (2012) doi:10.1155/2012/320648.

26. BPS. Profil Penduduk Lansia Provinsi Jawa Timur Tahun 2017. (2017).

27. Gibson, R. Principles of nutritional assessment. Oxford university press, USA (2005). doi:10.1111/j.1365-277x.2006.00665.x.

28. Chobanian, A. V. et al. Seventh report of the Joint National Committee on Prevention, Detection, Evaluation, and Treatment of High Blood Pressure. Hypertension 42, 1206-1252 (2003).

29. Kaplan, H. I., Sadock, B. J. \& Grebb, J. A. Sinopsis Psikiatri Klinis Jilid 1. in Kaplan - Sadock Sinopsis Psikiatro (2010).

30. Menteri Kesehatan Republik Indonesia No 67 Tahun 2015. PENYELENGGARAAN PELAYANAN KESEHATAN LANJUT USIA DI PUSKESMAS. PERMENKES doi:10.1145/3132847.3132886

31. Trivedi, D. Cochrane Review Summary: MiniMental State Examination (MMSE) for the detection of dementia in clinically unevaluated people aged 65 and over in community and primary care populations. Prim. Heal. Care Res. Dev. 18, 527-528 (2017).

32. Permenkes. Peraturan Menteri Kesehatan Republik Indonesia Nomor 28 Tahun 2019 Tentang Angka Kecukupan Gizi Yang Dianjurkan Untuk Masyarakat Indonesia. in vol. 4 75-84 (2019).

33. Baroni, L., Bonetto, C., Rizzo, G., Bertola, C., Caberlotto, L., \& Bazzerla, G. Association between Cognitive Impairment and Vitamin B12, Folate, and Homocysteine Status in Elderly Adults: A Retrospective Study. J. Alzheimer's Dis. 70, 441-451 (2019).

34. Ruitenberg, A., Ott, A., Van Swieten, J. C., 
Hofman, A. \& Breteler, M. M. B. Incidence of dementia: Does gender make a difference? Neurobiol. Aging 22, 575-580 (2001).

35. Maryam, R. S., Hartini, T. \& Sumijatun, S. Hubungan Tingkat Pendidikan dan Activity Daily Living dengan Demensia pada Lanjut Usia di Panti Werdha. J. Kesehat. Reproduksi 6, 45-55 (2016).

36. Takasugi, T., Tsuji, T., Nagamine, Y., Miyaguni, Y. \& Kondo, K. Socio-economic status and dementia onset among older Japanese: A 6year prospective cohort study from the Japan Gerontological Evaluation Study. Int. J. Geriatr. Psychiatry 34, 1642-1650 (2019).

37. Meng, X. \& D'Arcy, C. Education and dementia in the context of the cognitive reserve hypothesis: A systematic review with metaanalyses and qualitative analyses. PLoS One 7, e38268 (2012).

38. Russ, T. C. et al. Socioeconomic status as a risk factor for dementia death: Individual participant meta-analysis of 86508 men and women from the UK. Br. J. Psychiatry 203, 1017 (2013).

39. Kim, H., Kim, G., Jang, W., Kim, S. Y. \& Chang, N. Association between intake of $\mathrm{B}$ vitamins and cognitive function in elderly Koreans with cognitive impairment. Nutr. J. 13, 1-11 (2014).

40. Guilarte, T. R. Vitamin B6 and Cognitive Development: Recent Research Findings from Human and Animal Studies. Nutr. Rev. 51, 193198 (1993).

41. Wei, I. L., Huang, Y. H. \& Wang, G. S. Vitamin B6 deficiency decreases the glucose utilization in cognitive brain structures of rats. J. Nutr. Biochem. 10, 525-531 (1999).

42. Karlsson, I. Neurotransmitter changes in aging and dementia. Nord. J. Psychiatry 47, 41-44 (1993).

43. Erickson, K. I. et al. Greater intake of vitamins B6 and B12 spares gray matter in healthy elderly: A voxel-based morphometry study. Brain Res. 1199, 20-26 (2008).

44. Smith, A. D. et al. Homocysteine-lowering by $b$ vitamins slows the rate of accelerated brain atrophy in mild cognitive impairment: A randomized controlled trial. PLoS One 5, 1-10 (2010).

45. Moore, E. et al. Cognitive impairment and vitamin B12: A review. Int. Psychogeriatrics 24, 541-556 (2012).

46. Reynolds, E. Vitamin B12, folic acid, and the nervous system. Lancet Neurol. 5, 949-960 (2006).

47. Feldman, H. H. et al. Diagnosis and treatment of dementia: 2. Diagnosis. CMAJ 178, 825-836 (2008).

48. Garcia, A. Cobalamin and homocysteine in older adults: Do we need to test for serum levels in the work-up of dementia? Alzheimer's Dement. 3, 318-324 (2007).

49. Morris, M. S. \& Jacques, P. F. Folate and neurological function: Epidemiological perspective. Folate Heal. Dis. Second Ed. 325353 (2009).

50. Reynolds, E. H. The neurology of folic acid deficiency. Handb. Clin. Neurol. 120, 927-943 (2014).

51. Tehlivets, O. Homocysteine as a Risk Factor for Atherosclerosis: Is Its Conversion to $\mathrm{S}$ Adenosyl- L -Homocysteine the Key to Deregulated Lipid Metabolism? J. Lipids 1-11 (2011) doi:10.1155/2011/702853.

52. Kalaria, R. N. Neuropathological diagnosis of vascular cognitive impairment and vascular dementia with implications for Alzheimer's disease. Acta Neuropathol. 131, 659-685 (2016).

53. Mattson, M. P. \& Shea, T. B. Folate and homocysteine metabolism in neural plasticity and neurodegenerative disorders. Trends Neurosci. 26, 137-146 (2003).

54. Sachdev, P. S. Homocysteine and brain atrophy. Prog. Neuro-Psychopharmacology Biol. Psychiatry 29, 1152-1161 (2005).

55. Nagai, M., Hoshide, S., Ishikawa, J., Shimada, K. \& Kario, K. Visit-to-visit blood pressure variations: New independent determinants for cognitive function in the elderly at high risk of cardiovascular disease. J. Hypertens. 30, 15561563 (2012).

56. Sabayan, B. et al. Association of visit-to-visit variability in blood pressure with cognitive function in old age: Prospective cohort study. BMJ 347, f4600 (2013).

57. Böhm, M. et al. Systolic blood pressure variation and mean heart rate is associated with cognitive dysfunction in patients with high cardiovascular risk. Hypertension 65, 651-661 (2015).

58. Shang, S. et al. The age-dependent relationship between blood pressure and cognitive impairment: A cross-sectional study in a rural area of Xi'an, China. PLoS One 11, e0159485 (2016).

59. Gorelick, P. B. et al. Vascular contributions to cognitive impairment and dementia: A statement for healthcare professionals from the American Heart Association/American Stroke Association. Stroke 42, 2672-2713 (2011).

60. Carnevale, D. et al. Hypertension induces brain $\beta$-amyloid accumulation, cognitive impairment, and memory deterioration through activation of receptor for advanced glycation end products in brain vasculature. Hypertension $\mathbf{6 0}$, 188-197 (2012).

61. Vernooij, M. W. et al. Prevalence and risk factors of cerebral microbleeds: The Rotterdam Scan Study. Neurology 70, 1208-1214 (2008).

62. Pp, A., Skp, I. A. I. \& Suwanto, D. Peran Hiperhomosisteinemia dalam Aterosklerosis. 44, 645-651 (2017).

63. Ham, R., Sloane, P., Warshaw, G., Bernard, M. \& 
Flaherty, E. Primary care geriatrics: A casebased approach. in Primary Care Geriatrics: $A$ Case-Based Approach (2007). doi:10.1016/B978-0-323-03930-7.X5001-9.

64. Swan, G. E. \& Lessov-Schlaggar, C. N. The effects of tobacco smoke and nicotine on cognition and the brain. Neuropsychol. Rev. 17, 259-273 (2007).
65. Buchman, A. S. et al. Total daily physical activity and the risk of $A D$ and cognitive decline in older adults. Neurology 78, 1323-1329 (2012).

66. Machado, A. et al. Chronic stress as a risk factor for Alzheimer's disease. Rev. Neurosci. 25, (2014).

67. Selhub, J. Homocysteine Metabolism. Annu. Rev. Nutr. 19, 217-246 (1999). 